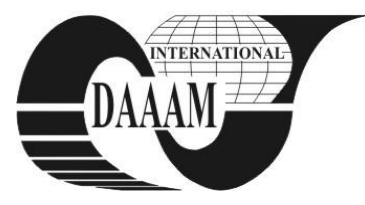

\title{
A MATURITY MODEL FOR QUALITY MANAGEMENT TO IMPROVE THE MANUFACTURING RESULTS
}

\author{
PASALODOS, D[avid] \& DOMINGO, R[osario]
}

\begin{abstract}
This paper develops a model to evaluate the maturity level of the quality management. The model represents a good tool supporting the improvement of organizations as well as its development. With the model, strategic business objectives as well as requirements of the processes are taken into consideration in order to achieve better business results and increasing the competence level of the organization. This perspective can be appreciated with results in terms of internal defect rate, order fulfillment rate and external defect costs, which are improved according the maturity model is implemented.
\end{abstract}

Key words: manufacturing, results model, quality, improvement

\section{INTRODUCTION}

In order to achieve and sustain a competitive advantage in the global economy, organizations today need to manage their resources efficiently. Organizations that endure in the time are those that make change an inexhaustible source of opportunities, adapting to them as quickly and efficiently as possible, with the application of the appropriate tools, as, for example, the model here presented.

Among the various theories of maturity models is to be highlight two of them, the Capability Maturity Model Integrated (CMMI) developed by Software Engineering Institute (SEI) of Carnegie Mellon University, which is a reference model which differs from other models by the fact be based on practices to fit every production domain and have a holistic and integrated organization, with the aim of achieving the objectives (Kugler Maag Cie, 2006; Chrissis et al., 2006) and the second model the ISO / IEC TR 15504 that through the definition of a model and framework assess the development process according to levels defined by the standard (ISO, 1998).

The impact of quality actions in the manufacturing is not new (González et al., 2000; Sousa, 2003) and the obtained results, due to the actions developed by productive environments in terms of quality, establish, at least partially, the fundament on which is based the improvement of their competitive position and allowing to maintain this position in a sustained way.

Quality management shows itself in this situation as a key factor to answer effectively and distinctive, the growing needs, desires and expectations of customers (Lin, 2007) by the application of designs, develops and adequate quality strategies, obtaining in this way a differential advantage respect the competitors.

A reference model to evaluate the quality management is therefore also a strategic option as no different as an ideal quality management and, in fact, represents an important innovation for production systems, which requires significant organizational change and a twist on the traditional management practices.
Based on those studies it was created a maturity model to evaluate the excellence in the quality management of manufacturing organizations. The application of a model created with the principles of quality system, suppliers, customers and manufacturing development enhances the creation of knowledge in all areas of industrial environments. The combination as well of the existing maturity model theories guarantees a deeper know-how, a better result as well a continuous improvement.

The model as related increase the internal knowledge in the organization by implementing a global/standardized process aligned with the organization's strategy and based on a common set of competences, taking advantage of possible synergies of locations with similar development needs and finding clever, effective ways to close the gaps.

To verify the efficiency and efficacy of the model created, it was applied in 11 manufacturing sites of a multinational company in the electromechanical industry. As further research a possibility is to apply this model in other organizations as well as continue with the evaluation of his improvement in the 11 sites installed.

\section{MATURITY MODEL FOR QUALITY MANAGEMENT}

Although a high degree of automation in any industrial systems, they are operated by people so the key is to give them the necessary tools so they can perform the functions more effectively and efficiently as possible, creating as much value added as possible.

The application of the model to evaluate excellence in quality management (or maturity level) is a global system approach (not an isolated area or program), and an integral part of corporate strategy, it works both horizontally and vertically across all functions and departments, involving all employees, giving a clear strategy to introduce and develop methods and tools as well as the respective improvement actions introduced after the respective evaluations to approach the management system to the reference model.

Thus, it is presented under the premise that the quality of a product or service is highly influenced by the quality of the processes that produce and maintain it as well as cooperation with suppliers (Yang et al., 2009) and knowledge the requirements and needs of customers (Pyon et al., 2010), as other authors have verified.

The developed model is divided in 4 sub-principles (system, supplier, manufacturing \& development and customers) and each of them is also divided in single methods and practices. See Table 1, where principles and sub-principles are shown.

The assessment system to evaluate the level of the organizations respect the model applied brings visibility and generates insights into how the organization performs, improving information exchange by enabling a feedback loop 
from broad cross-section of the model as well as knowledge sharing.

\begin{tabular}{|l|l|}
\hline \multirow{5}{*}{$\begin{array}{l}\text { Quality System } \\
\text { Management }\end{array}$} & $\begin{array}{l}\text { Definition of Quality Management } \\
\text { System }\end{array}$ \\
\cline { 2 - 2 } & $\begin{array}{l}\text { Implementation of Quality } \\
\text { Management System }\end{array}$ \\
\cline { 2 - 2 } & $\begin{array}{l}\text { Verification of Quality } \\
\text { Management System }\end{array}$ \\
\cline { 2 - 2 } Supplier Quality & $\begin{array}{l}\text { Development of Quality } \\
\text { Management System }\end{array}$ \\
\hline \multirow{5}{*}{$\begin{array}{l}\text { Management } \\
\text { Product Quality } \\
\text { Management }\end{array}$} & Supplier Selection \\
\cline { 2 - 2 } & New Component Approval \\
\cline { 2 - 2 } & Supplier Development \\
\cline { 2 - 2 } & $\begin{array}{l}\text { Supplier Non-conformities } \\
\text { Management }\end{array}$ \\
\hline \multirow{3}{*}{$\begin{array}{l}\text { Customer Quality } \\
\text { Management }\end{array}$} & Product Development \\
\cline { 2 - 2 } & Product Manufacturing \\
\hline & Market Surveillance Process \\
\hline
\end{tabular}

Tab. 1. Maturity Model for Quality Management

One of the key factors of successful organizations is the measurement and assessment of the resources they have and require. The application of the model itself and respective assessments facilitate the transmission of knowledge and the generation of skills and abilities that allow a suitable and efficient performance of its task, improving the benefits in the manufacturing in parallel with the level achieved base on the model. At the same time that an organization improves respect the model levels the targets will be more concrete with a smaller improvement framework, which will difficulty the progression of the level respect to the model compared to the previous evaluation, requiring a greater effort and more and deeper knowledge to incorporate the required methods and practices.

\section{RESULTS}

Evaluating in the organization a improvement can be appreciated since 2008, year of the introduction of the model. It is clear that those results are not only due to the model but since its integration the company has improved its results. Some of the improvements observed in the manufacturing sites where the model is applied with the corresponding implementation of methods and practices include the following higher productivity.

\begin{tabular}{|l|l|l|l|}
\hline & 2007 & 2008 & 2009 \\
\hline $\begin{array}{l}\text { IDR (parts per } \\
1000000)\end{array}$ & 360.091 & 321.909 & 244.273 \\
\hline OFR (\%) & 91.08 & 95.95 & 94.5 \\
\hline EDC (\%) & 1.05 & 0.99 & 0.82 \\
\hline
\end{tabular}

Tab. 2. Evolution of results

The organization experiences higher levels of productivity, owing to the training program which will give them all the tools and knowledge they require to increase the productivity. Productivity is also increased by improve communications in all ways, internally and external, horizontal and vertical, as by the application of the methods and practices of the model. Once communications channels are open, the model enables employees and management to learn and implement new ways of working, thus improving business operations for increased profits and productivity. Communication continues throughout the life of the model, this lets employees know that their actions matter and provides other employees with examples of how to make improvements. A first focus to see the improvement in productivity is the internal defect rate (IDR). An increase in quality in the 11 manufacturing sites had lead to lower costs by reducing reworks, scraps and unnecessary inspections are reduced or even, in the best case, eliminated. The model increases efficiency by improving resource utilization and lowering costs. See Table 2. A second focus of analysis can be the order fulfillment rate (OFR) or, in other words the rate of give the customer the quantity of products needed in the right time. Also this index has been improved in almost all manufacturing sites (only in one was not improved) since the application of the model, and it represents a global improvement (see Table 2).

And as third focus is representative the rate of external defect cost (EDC). The results demonstrate a clear improvement in Europe, a small improvement in Asia and no improvement in America but evenfalls the rate of external defects cost develops to a worldwide same level, reinforcing the sense of standardization of the model and increasing customer satisfaction.

\section{CONCLUSIONS}

The implementation of a maturity model for quality management, created for manufacturing plants, has improved the production results, in particular, in productivity indicators, such as internal defect rate, order fulfilment rate and external defect cost, in a global manner. Thus, the productivity is higher to apply the model. In the future the authors will research the outcomes in each type of manufacturing sites, to observe the differences between them and to carry out an internal bechmarking.

\section{REFERENCES}

Chrissis, M.B.; Konrad, M. \& Shrum, S. (2006). CMMI Second Edition: Guidelines for Process Integration and Product Improvement. Addison-Wesley, ISBN 978-0321154965

González, C.; Domingo, R. \& Sebastián, M.A. (2000). Técnicas de Mejora de la Calidad. UNED, ISBN 9788436241235

ISO/IEC TR 15504-5:1998. Information technology - Software process assessment Part 5: An assessment model and indicator guidance. International Organization for Standards, Geneve

Kugler Maag Cie GmbH (2006). CMMI for Development Version 1.2. Carnegie Mellon University

Lin, J. (2007). An object-oriented development method for Customer Knowledge Management Information. Knowledge-Based Systems, Vol.20, No.1, pp. 17-36, ISSN 0950-7051

Pyon, C.U.; Woo, J.Y. \& Park, S.C. (2010). Intelligent service quality management system based on analysis and forecast of VOC. Expert Systems with Applications, Vol. 37, No. 2, pp. 1056-1064, ISSN 0957-4174

Sousa, R. (2003). Linking quality management to manufacturing strategy: an empirical investigation of customer focus practices. Journal of Operations Management, Vol. 21, No.1, pp.1-18, ISSN 0272-6963

Yang, J., Wong, C.; Kee-hung, L. \& Ngome, A. (2009). The antecedents of dyadic quality performance and its effect on buyer-supplier relationship improvement. International Journal of Production Economics, Vol.120, pp. 243-251, ISSN 0925-5273 